УДК: 81:929 Белић А.

DOI: 10.18485/belic_slv.2016.1.ch2

Хилмар Валтер

\title{
СТУДИЈЕ И ПРОМОЦИЈА АЛЕКСАНДРА БЕЛИЋА НА ЛАЈПЦИШКОМ УНИВЕРЗИТЕТУ У ОКВИРУ РАЗВОЈА СРБОКРОАТИСТИКЕ
}

0. Научно дело Александра Белића имало је одлучујући значај за развој науке о српскохрватском језику после таквих изузетних научника као што су били Вук Караџић, Ђура Даничић, Ватрослав Јагић и Томо Маретић. Његов значај је био такође велик за интернационалну славистику. На ову чињеницу је било указивано у различитим радовима и према томе не треба да то посебно утврђујемо. ${ }^{1}$ 1980. године навршава се двадесетогодишњица смрти овог великог научника и то нас побуђује да се обратимо још једном његовом боравку у Лајпцигу, утолико више што се исте године навршава осамдесет година од његове промоције. Као и сви велики слависти његове генерације, млади Белић је добио веома солидно образовање у средиштима интернационалне славистике, којима су припадали у оно доба такође Москва и Лајпциг. Истакнута личност међу московским професорима код којих је слушао предавања и под утицајем којих је учинио прве кораке на подручју науке био је Ф. Ф. Фортунатов. У Лајпцигу су то били младограматичари, код којих је студирао два месеца.

Милоје Р. Николић је скупио релативно обиман материјал о студијама Белића у његовој домовини и у иностранству који се између осталог бави и његовим боравком у Лајпцигу. ${ }^{2}$ Он очигледно није имао могућности да прегледа материјал који се налази у архивама Карл-Маркс-Универзитета и даје веома интересантан увид у Белићев боравак у Лајпцигу. Из овог разлога је

1 Уп. Душан Јовић, O месту Ferdinanda de Saussura, Александра Белића u Leonarda Bloomfielda y лингвистици XX veka; Јужнословенски филолог XXIX (1-2/1972), стр. 59. и тамо наведена литература; Методологические проблемы истории славистики, ред. коллегия С. Б. Бернштејн, В. А. Ђаков, В. И. Злыднев, Д. Ф. Марков, А. Б. Мыльников; Москва 1978, стр. 118, 125, 298.

2 Милоје Р. Николић, Прилози упознавағуживота и рада Александра Белића; Наш језик, н.с., књ. ХI (1961), стр. 102. и сл., 273. и сл. 
први задатак нашег кратког излагања да оно што је Николић већ написао, допуни и прецизира.

Ако пођемо - са пуним правом - од тога да су методолошка и теоријска схватања његових учитеља имала утицај на каснија Белићева дела, онда је, полазећи од наше теме, сасвим разумљиво што је питање о Белићевом односу према схватањима младограматичара за нас посебно интересантно. Душан Јовић бавио се овим питањем пре неколико година и дошао је до веома занимљивих констатација, полазећи при томе углавном од Белићевих програмских схватања у делу O језичкој природи и језичком развитку. У својим Правцима... Милка Ивић такође кратко изражава мишљење о томе. ${ }^{3}$ Дозволите да и ми овом ставу нешто допринесемо.

1. Како пише М. Николић, у 1899. години Белић је имао намеру „продужити самостална испитивања... у упоредној граматици хтео је да се упозна с резултатима германске и келтске филологије, а тако исто с предавањима и семинарима немачких лингвиста у Лајпцигу“. $О$ тачном времену почетка Белићевих студија Николић не може да да̂ никаквих података. Студентска картотека и матрикула за 1899-1900. године Лајпцишког универзитета исказује да је Белић био иматрикулиран 8. новембра 1899. године. Као доба старости навео је 23 године. Становао је на Јоханис-плацу 4/5 у центру града у близини Универзитета. 27. јула 1900. године добио је завршно сведочанство, а 17. децембра 1900. године напустио је званично Универзитет. У складу с тим, налази се његово име такође у персоналном регистру Лајпцишког универзитета за зимски семестар 1899/1900. године и за летњи семестар 1900. године. ${ }^{5}$ Из „Протокола о издатим сведочанствима о студијама и моралном владању студената од 1. јула до 31. децембра 1900. године“ се Белић пријавио за следећа предавања:

3 Душан Јовић, ор. сіt., стр. 49 и сл.; исти аутор, О општелингвистичким схватанима проф. Александра Белића; Књижевност и језик, XVII (1970), бр. 2, стр. 129. и сл.; М. Ивић, Правии у лингвистиии, Љубљана 1963, стр. 70. Индиректно се додирује ова проблематика и у: Асим Пецо, Рад проф. Белића на проучавану наших дијалеката, Књижевност и језик, год. XVII (1970), бр. 2, стр. 135. и сл.

4 Op. cit., cтp. 298.

5 Personalverzeichnis der Universität Leipzig 1895/96-1900, стр. 55. и 56.

6 Сигнатура у архиву Карл-Маркс-Универзитета Лајпциг: Rep. I, Kap. XVI Litt. C, Sekt. VII, Nr. 61, Bd. 2. 
У зимском семестру:

- Код Бругмана: 1. „Елементи лингвистике“ (Увод у научно истраживање језика), посебно за класичне филологе, германисте и романисте

2. Увод у Хомерове песме, поред тумачења Илијаде књига Б

3. Лингвистичке вежбе у Индогерманском институту (грчки дијалектни списи и предавања)

- Код Лескина: $\quad$ Историјска граматика српскохрватског језика

- Код Виндиша: 1. Интерпретација текстова Stenzler-Pischelove елементарне књиге санскрита за почетнике

2. Ирска граматика

3. Ригведа

У летњем семестру:

- Код Лескина: $\quad$ 1. раматика литванског језика

2. Тумачење литванских текстова

3. Вежбе из читања старословенских текстова

- Код Виндиша: $\quad$ 1. Вежбе из ирског језика

2. Böhlingkova хрестоматија за санскрит

- Код Сиверса:

Фонетика

- Код Бругмана:

Лингвистичке вежбе у Индогерманском институту (тумачење грчких и италских натписа).

У књизи проканцеларијата Филозофског факултета за 1899-1900, стр. 32, налази се под бројем 128 Белићева пријава дисертације 3. августа 1900. године. Посебно интересовање заслужује акт о Белићевој промоцији, који је састављен истог дана. Осим тачних датума пријаве промоције, рецензије факултетских рецензената Лескина и Бругмана (Лескинова рецензија датирана је 28. септембра 1900. године, а Бругманова 30. септембра), решења факултета о закључној оцени и одобрења за усмени испит (9. октобра) и усменог испита (29. октобра 1900), ови документи садрже изразита указивања на цењење рада и личности А. Белића од стране познатих лајпцишких лингвиста: Лескина, Бругмана и Виндиша, посебно од стране Лескина. Тако се у акту налази - поред биографије - и једна Белићева молба да му се призна један семестар с обзиром на то да је сваки странац у Немачкој требало да има три семестра пре него што добије право на одбрану промоције, пошто његово одобрење за изостанак не дозвољава дужи боравак у Лајпцигу. Ова молба је пропраћена 
Лескиновим писмом проканцеларијату универзитета са следећом садржином: „Предлажем да се кандидату филозофије Белићу призна трећи семестар који му недостаје као странцу на немачком универзитету. Он је већ студирао у Београду, онда је апсолвирао потпуне студије у Москви. Публицирао је већ на подручју славистике, мени је познат као веома добро образован и одлично упућен у ову струку.“

Лескинова рецензија Белићеве дисертације има следећи дословни текст: „Словенски језици одликују се необично великим бројем и разноврсношћу градње деминутива. Они нису досада, чак ни у појединим језицима, били темељно обрађивани. Аутор покушава да попуни ову празнину. У његовом раду се не ради само о свођењу путем језичког поређења одговарајућих словенских суфикса на њихове старе облике, него о унутарњој историји творбе речи у самим словенским језицима. Суфикси који се употребљавају за деминуцију донекле су неодређени, они могу да имају детериоративно и амплификативно значење и употребљавају се за творбу речи које леже изван тога значења. Аутор покушава да пронађе у првом делу рада (стр. 1-36) полазне тачке за појаву појединих значења и њихово узајамно прелажење. Други део опширно обрађује поједине суфиксе, њихова различита стапања, претварање и трансформацију у облику и значењу кроз поједине словенске језике. Рад је у целини добро успео; његов главни недостатак лежи у готово свим Словенима својственој неумешности да јасно диспонују и на тај начин да избегну понављања. Предлажем оцену 2“. Независно од тога што споменути недостатак вероватно није лежао у карактерним својствима Словена, него је био образложен великом журбом са којом је овај рад морао бити написан, Лескинов предлог као и његова рецензија сведоче о веома позитивном ставу према властитом ученику. Бругман изражава потпуну сагласност са Лескиновом оценом „овог вредног и корисног рада“ и даје му такође оцену 2 (laudabilis).

Усмени испит из предмета „словенски“, „санскрит“ и „индогерманска лингвистика“ прошао је веома успешно, како то протокол утврђује. Лескин који је испитивао историју словенских језика и историјску и савремену граматику појединих језика, констатује: „Кандидат је показао врло добро знање на свим подручјима и могу да му дам оцену 1 “ ( 1 = egregia). Бругман је поставио питања о сродству индоевропских језика у целом и о разгранатости келтског и грчког језика, и сматра: „Кандидат је био углавном добро оријентисан.“ Виндиш је испитивао ведску

7 Ако је тако како пише М. Николић (op. cit.) да је тема за дисертацију била изабрана заједно са Лескином, онда је Белић имао само пола године на располагању за скупљање материјала, обрађивање и за писање! 
литературу и похваљује превод кандидата из ригведе. Обоје су му дали оцену 2. Као закључну оцену добија Белић IIa (admodum laudabilis).

Као што је познато, Белићев рад је штампан у Архиву словенске филологије 1901. године. ${ }^{8}$ Посебно одштампан, са нарочитим насловом „Inaugural-Dissertation“, био је предат Универзитету.

Изнете чињенице намећу закључак да је Белићев боравак у Лајпцигу, с једне стране, био веома напоран, што сведочи о његовој марљивости (коју је испољавао целог свог живота), а с друге стране, јасно говори о томе да је Белић већ био у оно доба добро познат у интернационалној славистици и промоцијом је утврдио ову своју репутацију.

2. Лајпцишки Белићеви учитељи били су познати представници младограматичарске школе и имали су велики удео у интернационалном ауторитету Лајпцишког универзитета као средишта лингвистике. У доба када је Белић боравио у Лајпцигу, Август Лескин (редовни професор од 1870) је остваривао младограматичарске идеје на подручју славистике, Карл Бругман (редовни професор од 1887) у индоевропеистици, Ернст Виндиш (редовни професор од 1877) на подручју индологије и келтологије (посебно ирског језика) и Едуард Сиверс (редовни професор од 1871) на подручју германистике (пре свега у науци о акценту и фонетици). ${ }^{9}$

Испитујући утицај младограматичара на Белића треба узети у обзир, по моме мишљењу, да је пре свога боравка у њиховој средини у Лајпцигу био изложен утицају једног другог великог лингвиста - Ф. Ф. Фортунатова. Полазећи од тога да се основна особина младограматичарских схватања састоји у томе да разматрају језик као творевину природних наука, због чега је садржина на другом плану, а облици су на првом плану, да настоје у постулирању важећих без изузетака гласовних закона као природних закона који се допуњавају аналогијом, да се разматрање језичких појава изолује од читавог система језика и од носиоца језика и да се свако испитивање признаје само тада као научно када је историјски образложено, ${ }^{10}$ у поређењу са

${ }^{8}$ Bd. XXIII (1901), стр. 134. и сл.

9 Уп. R. Fischer, August Leskien (1840-1916) у: Bedeutende Gelehrte in Leipzig, Karl-Marx-Universität Leipzig, Bd, I, 1965, стр. 57. и сл.; J. Mehlig, Ernst Windisch (1844-1918), ibid., стр. 63. и сл., G. Walther, Karl Brugmann (1849-1919), ibid., стр. 85. и сл., Th. Frings, Eduard Sievers (1850-1932), ibid., стр. 101. и сл.

10 УП. G. Helbig, Geschichte der neueren Sprachwissenschaft, Leipzig 1973, стр. 13. и сл., G. Walther, op. cit., стр. 89; В. А. Звегинцев, История языюкознания ХІХ и ХХ веков в очерках и извлечениях, I, Москва, 1960, стр. 151; М. Ивић, Правци $y$ 
схватањима Фортунатова може се видети да су у последњем пункту његова схватања у складу са младограматичарима. Сагласност постоји такође у приступу лингвистичким испитивањима, пошто се младограматичари, исто као и Фортунатов, строго оријентишу на језичке чињенице. С друге стране, Фортунатов се чврсто оријентише на повезаност језичке историје са историјом одговарајуће комуникативне заједнице (чиме се разликује од индивидуално-психолошке позиције младограматичара) и укључује семантичка питања принципијелно у своја истраживања. ${ }^{11}$

Д. Јовић пише да Белић „јасно каже да своја лингвистичка истраживања везује за младограматичарски метод и то образлаже на следећи начин: 'Са младограматичарским покретом ова се књига не слаже утолико што су младограматичари узимали као полазну и главну тачку формалне језичке особине не улазећи у саму суштину језика, али пошто је њихов начин испитивања у знатној мери реалистичан, иако по предмету и знатно сужен, њихови су резултати могли послужити у извесној мери и при изради ове књиге. “'12 На другом месту читамо код Јовића да Белић „недвосмислено подвлачи своју приврженост основним принципима младограматичарског метода“. ${ }^{13}$

Али схватања А. Белића у његовом делу О језичкој природи и језичком развитку, на којима се оснивају Јовићева утврђивања, не допуштају такав закључак. То потврђују такође Белићеви радови који се више оријентишу на практична питања. Ми смо мишљења да се Белић од почетка - већ за време својих студија и промоције у Лајпцигу и још раније (како пише М. Николић, Белић је добро познавао дела младограматичара још пре свога боравка у Лајпцигу ${ }^{14}$ ) није потпуно придружио схватањима младограматичара. Најбољи доказ је његова дисертација, која се истиче својим опширним семантичким интерпретацијама од многих радова који су писани у доба младограматичара, на што нарочито указује Лескин у својој рецензији.

лингвистищи, стр. 39. и сл.; О историји и утицају младограматичке школе види такође: R. Ružička, Historie und Historizität der Junggrammatiker, Linguistische Arbeitsberichte 15, Leipzig 1976, стр. 3. и сл.

11 Уп. В. А. Звегинцев, ор.cit., стр. 197. и сл., као и у истој књизи одломак из дела Ф. Ф. Фортунатова, Сравнительное языковедение, стр. 201. и сл.; М. Ивић, стр. 70 .

12 Д. Јовић, О месту..., стр. 70; цитат потиче из: А. Белић, О језичкој природи и језичком развитку, књ. II, Београд 1959, стр. 3-4.

${ }_{13}$ Ibid., cтp. 57.

${ }^{14}$ Op. cit., стр. 57. 
Ову безусловну усмереност према семантичкој страни језичких знакова у својим радовима образлаже касније Белић са приматом мишљења према језику: „... система знакова стоји, пре свега, у вези са системом значења или појмова; када се нешто у систему појмова измени, то обично има значаја и за систему знакова..." ${ }^{15}$ Како се овај развитак језика одвија - о томе Белић директно полемизира са младограматичарима, јер оно, на што се већ у горњем наведеном Јовићевом цитату подсећа, долази јасно до изражаја два ретка даље: „Оно што се у језику јавља као формална особина није никад у њему непосредно дато, већ је увек резултат често многих сложених процеса у које младограматичари нису улазили.“

Индивидуално-психолошком схватању младограматичара о језику супротставља Белић недвосмислено материјалистичку интерпретацију језика, пошто пише: „... ако се језик не може разумети без природе човекове, он се... још мање може разумети, ако се не претпостави да је и човек сам, са свима својим особинама, многовековни производ природе... Човек и природа - то је једна хармонична заједничка целина и зато се они подједнако огледају у изразу или саопштењима човековим. ${ }^{16}$ Овај материјализам, на коме се темеље његова теоретска схватања о језику, не може се дефинисати као марксистички, пошто Белић и људско друштво сматра као природну појаву ${ }^{17}$ и међусобни однос између човека и природе разматра само као реакцију човека према природи и на тај начин губи из вида активни утицај човека на природу и тиме један важан узрок за постанак језика. ${ }^{18}$

Један други важан закључак који истиче Белићева схватања о језику у поређењу са младограматичарима састоји се у интерпретацији сваке поједине језичке појаве као дела језичког система. То долази до изражаја, између осталог, у његовој теорији о синтагмама и у његовом комплексном прилазу лингвистичком опису ${ }^{19}$ што је принцип који се дијаметрално супротставља атомизму младограматичара. Белић је видео слабости хисторизма младограматичара, иако није одбацио историјску методу: „Не треба мислити да се овим одриче велики значај историјске граматике уопште или смањују њене велике заслуге за развитак лингвистике. Никада можда наша дисциплина није показала толико полета као у време младограматичара. И даље ће историјска граматика остати као једна од врло важних дисциплина лингвистичких; без ње се данашње

${ }_{15}$ О језичкој природи и језичком развитку, књ. І, Београд 1958, стр. 7.

${ }_{16}$ О језичкој природи..., књ. II, стр. 4.

17 Ibid.

${ }^{18}$ Ibid., cтр. 9.

19 Уп. О језичкој природи..., књ. І, стр. 8. и сл. 
стање језика не би могло разумети, исто онако као и ма који историјски или одређени период у развитку извесног језика. А њени се резултати морају разумети само као грађа за општу граматику, а не као упутство како се језик мора схватити уопште.“ Тако он препоручује такође историјску упоређивачку методу као средство за откриће еволуције језика. ${ }^{20}$ Али, уколико његов закључак о другим познатим лингвистима, што „када су хтели, нису се могли увек ослободити... од дубоко у њима усађеног историзма... “21 важи и за њега самог, показује, на пример, његова класификација глаголске конјугације у његовој Историји српскохрватског језика, где читамо, са једне стране: „Када се даје данашњи материјал језика, онда се као принцип поделе може узети само оно што у данашњим облицима постоји и што савремени представници једнога језика осећају као знак разлике или једнакости међу облицима."Његова класификација правилних глагола, с друге стране, оснива се у битним пунктовима на историјским критеријима. ${ }^{22}$ Али се Белић својим ставом да су историјска истраживања само један задатак науке о језику супротставља мишљењу Фортунатова, који одређује предмет лингвистике као „человеческий язык в его истории“, 23 док се корени за друга, овде споменута схватања Белићева, која се разликују од схватања младограматичара, у погледу на однос између језика и мишљења, језика и друштва и на систем језика, могу свакако налазити у идејама Фортунатова.

Најважнија Белићева сагласност са младограматичарима састоји се, без сумње, у томе што се у истраживачком раду придржавао строго језичких факата као полазне тачке и сагласно томе тражио јасно ограничење лингвистике према другим наукама ${ }^{24}$, иако је за њега круг језичких факата и предмет лингвистике шири него што су то замишљали младограматичари. Узмемо ли још историјску методу, коју је акцентирао у наведеном опсегу, можемо доћи до закључка да је Белић преузео од младограматичара оне методе које су на неки начин биле сагласне са концепцијом Фортунатова. При томе се не сме сметнути с ума да је Белић - како се то јасно огледа у његовим двема књигама - стално пратио интернационалну лингвистику и расправљао о њој, тако да се не може објаснити све у његовим схватањима као утицај Фортунатова и младограматичарске школе (на пример, он је очигледно познавао дела

${ }^{20}$ Ibid., стр. 4, и књ. II, стр. 7.

${ }^{21}$ Ibid.

${ }_{22}$ Књ. II, св. 2: Речи са конјугачијом, друго издаюе, Београд 1962, стр. 6. и сл.

${ }^{23}$ Ф. Фортунатов, ор. cit., стр. 201.

${ }^{24}$ Уп. О језичкој природи..., књ. I, стр. 4-7; књ. II, стр. 7. и сл. 
Хуга Шухарта, једног од највећих противника младограматичара). ${ }^{25}$ Пошто је Белић написао два теоретска дела тек при крају свога стваралачког пута, с обзиром на то било би вредно једном пропратити хронолошки на основу свих његових дела развој његових теоретских и методолошких схватања и тако упознати путеве преко којих је он, полазећи од Београда, Москве и Лајпцига, изградио свој сопствени оригинални допринос развитку језичке теорије; један задатак који у оквиру наше мале расправе није могао бити постављен нити решен.

${ }_{25}$ Уп. ibid., књ. I, стр. 5; за Huga Schuhardta уп. В. А. Звегинцев, ор. cit., стр. 264. и сл. 